\title{
WHY DO HIGHER-EDUCATION INSTITUTIONS PURSUE ONLINE EDUCATION?
}

\author{
Stephen Schiffman \\ Babson College and Franklin W. Olin College of Engineering
}

Karen Vignare

Michigan State University

Christine Geith

Michigan State University

\begin{abstract}
Using a unique item included for the first time in the Sloan Consortium's 2006 national survey of online learning, the authors analyze the reasons why higher-education institutions engage in online learning. Nine reasons are explored from contributing to extension efforts to returning a surplus. Eight of the nine reasons are found to vary in importance depending on the type of institution. Significant differences were found for associate-level institutions, for-profit institutions and large-enrollment institutions. The authors examine the findings for access and quality themes.
\end{abstract}

\section{KEYWORDS}

Online Education, Business Models, Business Strategy, Institutional Mission, Organizational Context, Organizational Goals, Access, Quality, Revenue

\section{INTRODUCTION}

\section{A. Background}

The rapid growth of online learning has created a complex organizational landscape in higher education [1]. A review of the literature by the authors [2] uncovered a lack of research into this new organizational landscape for online learning. There are case studies, suggested taxonomies, and surveys of some business practices. However, the authors could not identify any quantitative studies focused on the business models or business strategies for online learning used in U.S. degree-granting institutions.

To apply successful business models, strategies and practices from other institutions requires knowledge of the similarities and differences in their organizational contexts for online learning. For example, are they able to hire and fire faculty directly? Do they have the authority to create new curricula? What is their market? What is their cost structure? Readily available institutional information, such as type of institution, enrollment level, Carnegie classification and enrollment in online learning does not provide insight into the contextual factors that affect the business issues of online education.

No "markers" yet exist to differentiate and categorize the various online learning contexts across institutions. This is the goal of the authors' research and the focus of this first of two articles sharing the findings of their national quantitative study. 


\section{B. Previous Research}

The authors' research during the past three years has provided initial insight into the context question. Research has included exploratory interviews [3], case studies [4], feedback from seminars and workshops [5, 6, 7, 8], literature review and initial survey work [2].

An exploratory study of fifty people at eleven not-for-profit higher-education institutions by Schiffman [3] identified a number of current business concerns among innovators and early-adopters of online learning in U.S. institutions. The concerns included revenue distribution and generation, compensation, planning, course and degree regulation, marketing, student services, sources of capital, cost management and product development. These business issues were concerns even among institutions with a track record of successful growth in online enrollments. These issues and the differing organizational characteristics were further explored in a series of two Sloan Consortium workshops including nine case studies $[4,5]$.

Initial exploratory survey work with 110 institutions by Vignare, Geith and Schiffman [2] concluded that how an online learning unit is funded and how close it is to the academic core appears to have impacts on the level of control or influence it has over certain business-related and quality functions of online learning. This conclusion reinforced the relationship between business issues and organizational context.

In the previous findings [2, 3], standard organizational data did not fully explain the differences among contexts. Carnegie Classification did not entirely explain the different institutional missions and motivations for online learning. Also, the type of institutional control—profit or non-profit—did not fully explain the differences. Contextual factors such as enrollment trends, faculty demographics, and local economic climate also played a role in shaping the online learning organizations studied.

One aspect of organizational context put forth by Miller and Schiffman [9] speculated that institutions began their online learning programs with the intention to either extend access to degree programs to new off-campus students, or to improve the quality of existing programs. They also speculated that the way online learning was organized within any given institution would depend to some degree on which goalaccess or quality — the institution was pursuing.

\section{Two Key Variables}

The findings from the authors' research suggested focusing attention on two key variables to explore on a national level: (1) an institution's reasons for engaging in online learning; and (2) how institutions have organized their online learning initiatives. These two variables appear to hold the most promise for making sense out of the wide variety of organizational contexts for online learning. Two questions were prepared for inclusion in the 2006 Sloan Consortium National Survey of Online Learning, the most respected national survey of online education in the United States. This paper focuses on the results of the first variable listed above: the reasons for engaging in online learning. A second paper will focus on the results of the second variable.

\section{METHODOLOGY}

\section{A. Sample}

Responses were drawn from the 2,251 institutional responses to the 2006 Sloan Consortium Survey, Making the Grade [10] which went to every chief academic officer in the United States. For this analysis, 
the authors only wanted to include institutions which engage in online learning; therefore, only those institutions which replied to question five, indicating that currently they were offering online learning programs, were included in this analysis. An additional cut of the data was done to make sure those institutions who answered question five also gave responses to the two questions added by the authors. Of the total 2,251 respondents to the 2006 survey, 738 (33.2\%) are currently engaged in offering online learning programs and responded to both questions posed by the authors.

\section{B. Survey Question}

Using their previous research, including the internal and external drivers for online learning identified by Schiffman [3] and four items that were tested in the exploratory survey [2], the authors developed a list of common reasons for engaging in online learning. Nine reasons were selected to be included in question eight of the 2006 Sloan Consortium survey (Table 1). The survey respondents were asked to choose any of the nine responses and indicate their agreement to each response using a Likert Scale. Multiple responses were allowed.

Table 1. Question Eight From 2006 Sloan Consortium Survey

8. My institution is engaged in online learning to: Please select the most appropriate response for each item. Please skip to the next question if your school does not have any online offerings.

\begin{tabular}{|l|l|l|l|l|l|l|l|}
\hline & $\begin{array}{c}\text { 1 Strongly } \\
\text { Disagree }\end{array}$ & $\mathbf{2}$ & $\mathbf{3}$ & $\mathbf{4}$ Neutral & $\mathbf{5}$ & $\mathbf{6}$ & $\begin{array}{c}\mathbf{7} \text { Strongly } \\
\text { Agree }\end{array}$ \\
\hline Return a surplus to the institution & & & & & & & \\
\hline Contribute to the extension efforts & & & & & & & \\
\hline $\begin{array}{l}\text { Contribute to traditional on-campus } \\
\text { student retention }\end{array}$ & & & & & & & \\
\hline Increase the diversity of student body & & & & & & & \\
\hline Enhance value of university brand & & & & & & & \\
\hline $\begin{array}{l}\text { Increase the speed to graduation for } \\
\text { traditional on-campus students }\end{array}$ & & & & & & & \\
\hline Reduce or contain costs & & & & & & & \\
\hline Provide pedagogic improvements & & & & & & & \\
\hline $\begin{array}{l}\text { Get students from new geographic } \\
\text { regions or new markets of students }\end{array}$ & & & & & & & \\
\hline
\end{tabular}

\section{Data Analysis}

Responses to the 2006 Sloan Consortium survey [10] were linked to institutional descriptive data via the Integrated Postsecondary Education Data System, enabling analysis at several levels of granularity. For each of the nine possible reasons, data were analyzed in three different ways:

1. By three types of institutional control:

a. Public

b. Private not-for-profit 
c. Private for-profit

2. By five Carnegie classifications:

a. Doctoral/Research

b. Master's

c. Bachelors

d. Associate

e. Specialties

3. By five categories of enrollment size:

a. Large (Greater than 15,000)

b. Medium to large $(7,500$ to 14,001$)$

c. Medium $(3,001$ to 7,499$)$

d. Small to medium $(1,501$ to 2,999$)$

e. Small (Less than 1,500)

The standard tests used were an initial ANOVA to look for statistical differences while using Levene's test of homogeneity. If Levene showed a significant difference then nonparametric tests were performed. When Levene indicated the data sets were homogeneous despite what seem like large sample size differences, ad hoc tests of Tukey and Bonferroni were performed to determine pairwise statistical differences. Furthermore, even if Levene was not statistically different (i.e. normal) non-parametric tests were still performed to confirm the statistical differences found in previous tests.

\section{FINDINGS}

Table 2 shows the percent of all survey respondents who either agreed or strongly agreed in the agree column and those who answered disagreed or strongly disagreed with a particular statement. Table 2 shows, in descending order of agreement, the statements from question eight on the survey.

Table 2. Agreement with Reasons for Engaging in Online Learning

\begin{tabular}{|l|c|c|}
\hline Reason & \% Agree & \% Disagree \\
\hline \hline Get new students & 57.0 & 5.1 \\
\hline Contribute to extension efforts & 46.0 & 6.9 \\
\hline Enhance brand & 32.2 & 11.3 \\
\hline \hline On-campus student retention & 31.6 & 11.3 \\
\hline Provide pedagogic improvements & 28.7 & 8.7 \\
\hline Increase student diversity & 23.8 & 12.0 \\
\hline Return a surplus to institution & 20.9 & 24.8 \\
\hline Increase student speed to graduation & 20.4 & 17.1 \\
\hline Reduce or contain costs & 12.8 & 23.0 \\
\hline
\end{tabular}

Results of the statistical analysis are summarized below. The findings and associated statistical tests are in Appendix A. 
Get new students: There is no statistically significant difference in responses by control, types of degree, or enrollment size. Based on several tests, no differences could be found among the Likert Scale rankings of agreement.

Contribute to extension efforts: There is a statistically significant difference by type of institutional control. Statistical tests show that public institutions agree with this more as a reason for being involved in online learning compared with privates or for-profits. The pair-wise analysis upholds a strong statistical difference between public and for-profits. There is a statistically significant difference at the third decimal place which rounds up to .05 between Public and Private not for-profit.

Enhance brand: Analysis shows a statistically significant difference by institutional control. Data indicate that for-profits agree with this statement more than privates or publics. The initial ANOVA upheld a statistical difference but the post ad-hoc tests resulted in a statistical difference for only forprofits versus publics. A nonparametric test did uphold statistical differences among public and private, for-profit and private, and not for-profit and private for profit.

On-campus student retention: The only statistically significant difference is among the Carnegie classifications and data show that associate institutions agree with this more than other Carnegie classifications.

Provide pedagogic improvements: The only statistically significant difference exists among the Carnegie classifications. The data shows that associate institutions agree with this more than other Carnegie classifications but are only statistically significant compared to specialized institutions.

Increase student diversity: The only statistically significant difference exists among the Carnegie classifications and type of institutional control. The data show that associate institutions agree with this more than other Carnegie classifications. Associates are statistically different from Masters, Baccalaureate and Specialized institutions. The data also show the private not-for-profit disagree with this reason more than the others and that increasing diversity is statistically different for private not-for-profit versus both public and private for-profit.

Return a surplus to institution: The only statistically significant difference is that private institutions, both for-profit and not-for-profit, agree with this statement more than public institutions. It is noteworthy that because public institutions represent a larger group in the sample, their responses shifted the percentage of agreement to a negative rating.

Increase student speed to graduation: There is a statistically significant difference by enrollment size and by Carnegie classifications. The data indicates that institutions with larger enrollments agree with this statement compared to institutions with smaller enrollments. However, only institutions with enrollments under 1,500; between 3,000 and 7,499; between 7,500 and 14,999; and over 15,000, are statistically different. The exception to the general principle that institutions with larger enrollments agree more with this statement, are institutions with enrollment between 1,500 and 2,999; and between 3,000 and 7,499. Associate institutions agree with this more than other types of Carnegie classifications and are significantly different from masters, baccalaureate and specialized institutions. Baccalaureate institutions disagree more with this statement than other institutions and are significantly different in their response from doctoral, masters, associates and specialized institutions. 
Reduce or contain costs: Analysis indicates statistically significant difference by control and by types of Carnegie classification. Data shows that for-profits agree with this more compared with publics or private not-for-profits, but only private not-for-profit and for-profits are statistically different. Associates rank their agreement as higher than other institution types. Associate institutions are statistically different from baccalaureate and masters institutions. More respondents disagreed with this statement than agreed.

\section{LIMITATIONS}

Survey bias exists from only including institutions that have commenced online learning. However, it is critical to start with engaged institutions to look for differences in reasons for offering online learning and to ultimately be able to provide insight to institutions considering offering online learning. In addition, because there are multiple independent variables within the data, the statistical analysis presented may still have multiple collinearity effects.

\section{DISCUSSION}

The single reason, across all types of respondents, to engage in online learning with which the majority (57\%) of institutions agreed was "Get students from new geographic regions or new markets of students." The number two reason, with which nearly half (46\%) of respondents agreed, was "Contribute to extension efforts." The other seven reasons were selected by a minority of respondents (32.2\%-12.8\%). There were, however, interesting differences when examining types of institutional control, types of institution and enrollment levels.

\section{A. Differences by Type of Institutional Control}

Based on their past research, the authors expected to find that the type of institutional control would make a difference in the ranking of reasons for engaging in online learning. According to the survey, for-profit institutions agreed with "enhancing the brand," "returning a surplus to the institution" and "reducing or maintaining costs" as more important reasons than did public or private institutions.

Survey results also indicate that public institutions agreed with "contributing to extension efforts" as more important when compared to for-profit or private institutions. Publics also ranked "returning a surplus to the institution” as less important compared to for-profit or private institutions.

These results contradict an earlier survey by the authors [2] where "returning a surplus to the institution" was one of the top two "very important" reasons for engaging in online learning. The authors argue that the terms "extension" and "new students," could imply new revenue in the context of public institutions whose missions are to have an impact in communities. The terms "extension" and "new students" may be more acceptable to publics than agreeing with "returning a surplus." "Enhancing the brand," "returning a surplus" and "reducing and maintaining costs" are familiar terms in the context of for-profit institutions.

The authors also speculate, based on their experience, that the reason more respondents disagreed than agreed with two other money-related reasons (return a surplus and reduce or maintain costs) may be more a reflection of the level of institutional results in those areas, as opposed to reasons for engagement.

One other difference exists among institutional control types. The private not-for-profit institution disagrees more than public and private for-profit that online learning can help increase the diversity of student body. 


\section{B. Differences by Carnegie Classification}

A significant finding is that compared to bachelor and doctoral institutions, associate institutions place more importance in their agreement on several of the nine reasons: "retention for on-campus students," "pedagogical improvements," "speed to graduation," "diversity of student body" and "reducing or maintaining costs." While associate institutions agree more with statements, it is critical to juxtapose these findings with the facts that as a group these institutions have higher online learning enrollments and have been offering online longer than many other institutions. Associate institutions continue to enroll more online learning students than all other types of Carnegie classifications [10,11, 12, 13]. Allen and Seaman 2006 [10] data show 50\% $(1,547,522)$ of the 3.1 million students enrolled in the Fall of 2005 were in associate institutions. In other words, Associates could have more experience since they enroll more students.

\section{Differences by Enrollment}

Survey results indicate only one significant difference by enrollment size. Institutions with enrollments greater than 7,500 agree "increasing student speed to graduation" is a more important reason for engaging in online learning compared to institutions with smaller enrollments.

\section{Quality and Access Perspectives}

Another way to examine the reasons for engaging in online learning is to view the reasons through the lenses of access and quality [9]. Each of the nine possible responses to the survey question could be interpreted as either an "access" motive or a "quality" motive. The authors believe that most people would agree that the responses "get new students" and "contribute to extension efforts" are "access" goals; and that "provide pedagogic improvements", "improve on-campus student retention", "increase students diversity" and even "increase student speed to graduation" are "quality" goals. The remaining three responses relating to brand or money and were not as easily categorized, but the authors chose to interpret them as "quality" goals because they reflect ubiquitous characteristics of "high quality" institutions such as being financially healthy and well-known.

The following table is a restatement of Table 2, with an extra column added showing the authors' interpretation as to whether each response is an access or quality goal. Through the lenses of access and quality, data seem to imply that institutions more generally agree that they are pursuing online education as means to extend access rather than to improve quality.

Table 3. Access and Quality Goals

\begin{tabular}{|l|c|c|c|}
\hline Reason & \% Agree & \% Disagree & A/Q \\
\hline Get new students & 57.0 & 5.1 & $\mathrm{~A}$ \\
\hline Contribute to extension efforts & 46.0 & 6.9 & $\mathrm{~A}$ \\
\hline Enhance brand & 32.2 & 11.3 & $\mathrm{Q}$ \\
\hline \hline On-campus student retention & 31.6 & 11.3 & $\mathrm{Q}$ \\
\hline Provide pedagogic improvements & 28.7 & 8.7 & $\mathrm{Q}$ \\
\hline Increase student diversity & 23.8 & 12.0 & $\mathrm{Q}$ \\
\hline Return a surplus to institution & 20.9 & 24.8 & $\mathrm{Q}$ \\
\hline
\end{tabular}




\begin{tabular}{|l|l|l|l|}
\hline Increase student speed to graduation & 20.4 & 17.1 & $\mathrm{Q}$ \\
\hline Reduce or contain costs & 12.8 & 23.0 & $\mathrm{Q}$ \\
\hline
\end{tabular}

\section{CONCLUSION}

Getting students from new geographic regions or new markets of students is the top reason for engaging in online learning according to respondents to the 2006 Sloan Consortium national survey of online learning. Eight other reasons were also surveyed with public institutions favoring "contribute to extension efforts" and for-profit institutions favoring "enhancing the brand," "returning a surplus to the institution" and "reducing or containing cots." Associate institutions favored a number of quality-related reasons including retention, pedagogic improvements and student diversity.

These findings are the first quantitative national data focused on reasons for engaging in online learning across all institutional types of control, Carnegie classifications and enrollment levels. As such, they begin to fill a gap in the literature and shed some light on the various organizational contexts for online learning.

This is the first in a series of articles analyzed the reasons for engaging in online learning. The authors conclude from the results that in general, access-related reasons are more prevalent than quality-related reasons in 2006. The second article in the series analyzes responses to "how are you organized for online learning” and will provide insights into the relationship between the reasons and the organizational implementations of online learning.

\section{SUGGESTIONS FOR FUTURE RESEARCH}

Several findings point to the need for additional research. How much might the terms "contribute to extension efforts" and "get new students" be obscuring potential revenue-related reasons for engaging in online learning? Understanding the full meanings of the terms may help identify meaningful similarities in business issues and practices between public and for-profit contexts.

Another area to examine is to what extent the nine reasons are "life cycle" dependent. Are associate institutions more focused on quality because they have been offering online education longer than other types of institutions, or are they focused on quality due to the characteristics of their faculty or student body? Did associate institutions start out with an access reason that evolved into a quality reason? Will other types of institutions begin to view online education as a means to improve the quality of education once their access goals have been reached? Is there a critical success point (also referred to as a "tipping point”) where institutions' reasons for offering online education change? Answers to these questions can only be answered by collecting data on the reasons for engaging in online learning over time.

\section{ABOUT THE AUTHORS}

Dr. Stephen Schiffman is currently Associate Professor of Entrepreneurship at both Babson College and the Franklin W. Olin College of Engineering. At Babson, Steve was dean of the undergraduate program for 8 years while a new undergraduate business curriculum was developed and launched in the fall of 1996. In 1997, the Pew Charitable Trusts recognized this effort by selecting Babson for a Pew Leadership Award for renewal of undergraduate education. Steve holds a Ph.D. in mathematics from Dartmouth College as well as an M.S. in management from Sloan School, MIT. He has taught at the University of 
Colorado and Colorado College, and, prior to joining Babson College, he worked at Digital Equipment Corporation.

Karen Vignare currently serves as the Director of MSU Global Ventures at Michigan State University. In that role, Karen is responsible for creating online entrepreneurial approaches for extending both noncredit and credit programs at MSU. She was the Sr. Research Analyst for the Online Learning Department at the Rochester Institute of Technology. Karen was a full-time faculty member at SUNYAlfred State in the marketing, retail, and computer technology fields. She also served as a vice president and political economist for a Wall Street financial firm. She publishes regularly on various topics in online learning. She has an MBA from the University of Rochester's William Simon School of Business and a BS from Frostburg State University in political science and economics. She is currently attending doctoral classes at Nova Southeastern University.

Dr. Christine Geith is Assistant Provost and Executive Director of Michigan State University's MSU Global, the university's entrepreneurial business unit that works with academic partners across the campus and worldwide to develop online institutes, programs and services. She is responsible for developing strategic frameworks and business models and leading all activities that impact revenue growth. Dr. Geith's research interests include costs, benchmarks and business models for online and blended learning. Dr. Geith has over fifteen years of experience in online learning including four years as director of MSU Global Ventures. Prior to joining MSU, Dr. Geith was executive director of e-learning at Rochester Institute of Technology. Dr. Geith holds an M.B.A. from Rochester Institute of Technology and a Ph.D. from the University of Nebraska-Lincoln in Higher Education Leadership.

\section{ACKNOWLEDGEMENTS}

The authors wish to thank the Sloan Consortium for its support and dissemination of this research. Thanks go especially to Jeff Seaman who provided data from the 2006 Sloan Consortium annual survey.

\section{REFERENCES}

1. Geith, C. North American Perspective: Business Models and Practices for Online Learning in the United States, Open and Distance Learning Association of Australia, Breaking Down the Boundaries, Conference Proceedings, 2005. http://www.odlaa.org/events/2005conf/nonref/odlaa2005Geith.pdf.

2. Vignare, K., C. Geith and S. Schiffman. Business models for online learning: An exploratory survey. Journal of Asynchronous Learning Networks 10(2): May 2006.

3. Schiffman, S. Business issues in online education. In: J. Bourne and J. Moore (Eds.), Elements of Quality Online Education, Volume 6, Needham, MA: The Sloan Consortium, 2005.

4. Lorenzo, G. Business models for online education. Journal of Asynchronous Learning Networks 10(2): May 2006.

5. Geith, C., S. Schiffman and K. Vignare. Identifying successful business strategies for distance learning. The Sloan-C View 4(6): June 2005.

6. Vignare, K., S. Schiffman, C. Geith and T. Bishop. Successful business models and practices for distance and online education. National University Telecommunications Network Annual Conference, San Francisco, CA, June 2005. http://www.nutn.org/annual_event/2005/presentations /Vignare_BusinessModelsforDE_NUTN2005.ppt. 
7. Schiffman, S. and K. Vignare. Identifying successful business strategies for distance learning. Eleventh Sloan Consortium International Conference on Asynchronous Learning Networks, Orlando, FL, November 2005. http://www.sloan-c.org/conference/proceedings/2005/ppt/5008.ppt.

8. Schiffman, S. An institutional perspective on online education. Sloan Consortium Summer 2006 Conference, Baltimore, MD, August 2006.

9. Miller, G. and S. Schiffman. ALN business models and the transformation of higher education. Journal of Asynchronous Learning Networks 10(2): May 2006.

10. Allen, I. E. and J. Seaman. Making the Grade: Online in the Education in the United States, 2006. Needham, MA: Sloan Consortium, 2006. http://www.sloan-c.org/publications/survey/survey06.asp.

11. Allen, I. E. and J. Seaman. Growing by Degrees: Online Education in the United States, 2005. Needham, MA: The Sloan Consortium, 2005. http://www.sloan-c.org/publications /survey/survey05.asp.

12. Allen, I. E. and J. Seaman. Entering the Mainstream: The Quality and Extent of Online Education, 2003 and 2004. Needham, MA: The Sloan Consortium, 2004. http://www.sloan-c.org /publications/survey/survey04.asp.

13. Allen, I. E. and Seaman, J. Sizing the Opportunity: The Quality and Extent of Online Education in the United States 2002-2003. Needham, MA: The Sloan Consortium, 2003. http://www.sloan-c.org /publications/survey/survey03.asp.

\section{APPENDIX}

Table 1. p Values by Carnegie Class versus Reasons for Online Learning

\begin{tabular}{|c|c|c|c|c|c|}
\hline & Doctoral & Masters & $\begin{array}{l}\text { Baccalau- } \\
\text { reate }\end{array}$ & Associates & Specialized \\
\hline $\begin{array}{l}\text { Contribute to traditional } \\
\text { on-campus student } \\
\text { retention }\end{array}$ & \multicolumn{5}{|c|}{$\begin{array}{c}\text { Statistically Significant difference } \mathrm{p}=.00 \\
\text { Follow up tests (Kruskal-Wallis }(\mathrm{KW}) \text { ) indicate only Associates are significantly } \\
\text { different }\end{array}$} \\
\hline Associates & $\mathrm{KW} p=.00$ & $\mathrm{KW} \mathrm{p}=.00$ & $\mathrm{KW} p=.00$ & & $\mathrm{KW} p=.00$ \\
\hline $\begin{array}{l}\text { Increase the diversity of } \\
\text { student body }\end{array}$ & \multicolumn{5}{|c|}{$\begin{array}{c}\text { Follow up KW tests showed Mean Rank of Associates is higher and statistically } \\
\text { different than Masters, Baccalaureate, and Specialized }\end{array}$} \\
\hline Associates & & $\mathrm{KW} p=.001$ & $\mathrm{KW} p=.001$ & & $\mathrm{KW} \mathrm{p}=.001$ \\
\hline $\begin{array}{l}\text { Increase the speed to } \\
\text { graduation for traditional } \\
\text { on-campus students }\end{array}$ & \multicolumn{5}{|c|}{$\begin{array}{l}\text { Follow up KW tests found both Baccalaureate and Associates were different. } \\
\text { Mean Ranks were higher for Associates compared to others while Mean Ranks } \\
\text { were lower for Baccalaureate institutions }\end{array}$} \\
\hline Associates & & $p=.023$ & $p=.000$ & & $\mathrm{p}=.041$ \\
\hline Baccalaureate & $p=.027$ & $p=.002$ & & $p=.000$ & $\mathrm{p}=.002$ \\
\hline Reduce or contain costs & \multicolumn{5}{|c|}{$\begin{array}{l}\text { Follow up tests indicate while Associates Mean Rank is higher than other } \\
\text { Carnegie classes, KW p values are only statistically significant between } \\
\text { Associates and Masters KW p=.049 } \\
\text { And between Associates and Baccalaureates KW p=.014 }\end{array}$} \\
\hline $\begin{array}{l}\text { Provide pedagogic } \\
\text { improvements }\end{array}$ & \multicolumn{5}{|c|}{$\begin{array}{c}\text { Follow tests indicate while Associates Mean Rank is higher than other Carnegie } \\
\text { classes that only KW p values are statistically significant } \\
\text { Between Associates and Specialized KW p }=.023\end{array}$} \\
\hline
\end{tabular}


Table 2. p Values by Institutional Control versus Reasons for Online Learning.

\begin{tabular}{|c|c|c|c|}
\hline & Public & Private Not-for-Profit & Private for Profit \\
\hline $\begin{array}{l}\text { Return a surplus to the } \\
\text { institution }\end{array}$ & \multicolumn{3}{|c|}{$\begin{array}{l}\text { Statistically significant difference } \mathrm{p}=.000 \\
\text { Public institutions rank returning a surplus lower than either Private not For-Profit } \\
\text { and Private For-Profit }\end{array}$} \\
\hline Public & & $\mathrm{KW} \mathrm{p}=.000$ & $\mathrm{KW} p=. .001$ \\
\hline $\begin{array}{l}\text { Contribute to extension } \\
\text { efforts }\end{array}$ & \multicolumn{3}{|c|}{$\begin{array}{l}\text { Statistically significant difference } \mathrm{p}=.014 \\
\text { Public institutions rank returning a surplus lower than either Private not For-Profit } \\
\text { and Private For-Profit }\end{array}$} \\
\hline Public & & $\mathrm{KW} \mathrm{p}=.047$ & $\mathrm{KW} p=.001$ \\
\hline $\begin{array}{l}\text { Increase the diversity of } \\
\text { student body }\end{array}$ & \multicolumn{3}{|c|}{$\begin{array}{l}\text { Statistically significant difference } \mathrm{p}=.006 \\
\text { Private not for-profit rank this as less important than either Publics or Private for- } \\
\text { profit }\end{array}$} \\
\hline $\begin{array}{l}\text { Private not for } \\
\text { profit }\end{array}$ & $\mathrm{KW} p=.006$ & & $\mathrm{KW} p=.016$ \\
\hline $\begin{array}{l}\text { Enhance value of } \\
\text { university brand }\end{array}$ & \multicolumn{3}{|c|}{$\begin{array}{l}\text { Statistically significant difference } \mathrm{p}=.037 \\
\text { Private for-profit rank enhancing brand as higher than Public or Private not-for- } \\
\text { profit }\end{array}$} \\
\hline Private for profit & $\mathrm{KW} p=.003$ & $\mathrm{KW} \mathrm{p}=.015$ & \\
\hline $\begin{array}{l}\text { Increase speed to } \\
\text { graduation for traditional } \\
\text { on-campus students }\end{array}$ & \multicolumn{3}{|c|}{$\begin{array}{l}\text { Statistically significant difference } \mathrm{p}=.000 \\
\text { While both public and private for profit rank increasing speed to graduation } \\
\text { higher there is only a statistically significant difference between private not-for- } \\
\text { profit and public } \mathrm{KW} \mathrm{p}=.000\end{array}$} \\
\hline Reduce or contain costs & \multicolumn{3}{|c|}{$\begin{array}{l}\text { Statistically significant difference } p=.009 \\
\text { While both public and private for profit rank reducing or containing costs higher } \\
\text { there is only a statistically significant difference between private not-for-profit } \\
\text { and private for profit } \mathrm{KW} p=.002\end{array}$} \\
\hline
\end{tabular}

Table 3. p Values by Enrollment Size versus Reasons for Online Learning.

\begin{tabular}{|l|l|l|l|l|l|}
\hline & $\begin{array}{l}\text { Less than } \\
1.5 \mathrm{~K}\end{array}$ & $\begin{array}{l}\text { Between 1.5K } \\
\text { and 3K }\end{array}$ & $\begin{array}{l}\text { Between 3K } \\
\text { and 7.5K }\end{array}$ & $\begin{array}{l}\text { Between 7.5K } \\
\text { and 15K }\end{array}$ & Over 15K \\
\hline $\begin{array}{l}\text { Increasing speed to } \\
\text { graduation for } \\
\text { traditional on-campus } \\
\text { students }\end{array}$ & \multicolumn{5}{|l|}{ Statistically significant difference $\mathrm{p}=.002$} \\
\hline Less than 1.5K & & & $\mathrm{KW} \mathrm{p=.035}$ & $\mathrm{KW} \mathrm{p.006}$ & $\mathrm{KW} p=.022$ \\
\hline Between 3.5 to 7K & & $\mathrm{KW} \mathrm{p=.011}$ & & & \\
\hline
\end{tabular}

NOTE: For a complete data set, readers are encouraged to contact Karen Vignare at vignare@msu.edu. 